\title{
APPLICATION OF COPYWRITING ELEMENTS IN SOCIAL MEDIA ADVERTISING DRINKING PRODUCTS NOW IN CREATING CONSUMER INTEREST
}

\author{
Oleh: \\ Jesslyn 1 \\ Glorya Agustiningsih ${ }^{2}$
}

\begin{abstract}
One of them is creative contents uploaded by @xingfutang_indonesia on Instagram. Creative content creation cannot be separated from visual and copywriting elemts. In this case, copywriting becomes important in providing information to the target market. Referring to the concept, this study aims to determine the applied elements of copywriting which include headline and slogans, company taglines, and call to action used in creativecontents on @xingfutang_indonesia account on Instagram. The research method used is a descriptive qualitative approach with content collection documentation and interviews as data collection techniques. The results of the research are beneficial for the scientific development of the field of communication, especially for the advertising industry in a practical way.
\end{abstract}

Keywords: Advertising, Social Media, Creative Content, Copywriting, Instagram

\begin{abstract}
ABSTRAK
Bentuk konten kreatif yang beragam dapat ditemukan dengan mudah di berbagai akun media sosial Instagram Salah satunya adalah konten kreatif yang diunggah oleh akun @xingfutang_i ndonesia di Instagram Pembuatan konten kreatif tidak lepas dari elemen visual dan copywriting. Dalam hal ini, copywriting menjadi hal penting dalam memberikan informasi terhadap target pasar. Mengacu pada konsep tersebut, penelitian ini bertujuan untuk mengetahui terapan elemen-elemen copywriting yang mencakup headline and slogans, company tagline, dan call to action pada konten kreatif akun media sosial Instagram @xingfutang_indo nesia. Metode penelitian mengguna ka n pendekatan kualitatif deskriptif dengan dokumentasi kumpulan konten dan wawancara sebagai teknik pengumpulan data. Hasil dari penelitian bermanfaat bagi pengembangan keilmuan bidang komunikasi, khususnya bagi industri periklanan secara praktis.
\end{abstract}

Kata Kunci: Iklan, Media Sosial, Konten Kreatif, Copywriting, Instagram

\footnotetext{
${ }^{1}$ Alumni Program Studi Ilmu Komunikasi - Institut Bisnis dan Informatika Kwik Kian Gie

${ }^{2}$ Alamat kini: Institut Bisnis dan Informatika Kwik Kian Gie, Jln Yos Sudarso Kav. 87 Sunter, Jakarta 14350 Penulis untuk Korespondensi: Telp. (021) 65307062 Ext. 705. E-mail: Gloria.agustiningsih@kwikkiangie.ac.id.
}

Program Studi Ilmu Komunikasi - Institut Bisnis dan Informatika Kwik Kian Gie 


\section{INTRODUCTION}

The development of business in the present makes business competition increasingly fierce. This competition has finally triggered entrepreneurs to start taking advantage of technological sophistication in promoting their products. The more competitive the business environment requires the company to determine a marketing communication strategy, segme nt the market and the more important it is for the company to align its marketing mix with the selected targets in order to allocate resources effectively while providing the highest effect or value for its customers.

One way is to use advertising. Advertising is the main tool for producers to influence their consumers. Advertising or what is known as advertising is any form of non-personal communication about an organization, product, service, or idea paid for by a sponsor (Morissan, 2010: 17). This technological development makes changes to advertising activities. The emergence of the internet helps marketers to reach a wider range of potential consumers anytime and anywhere.

Coupled with the emergence of social media, many marketers have switched from conventional media to social media because advertising costs are much cheaper and can be measured. Social media is a site-based feature that can form networks and allow people to interact in a community. On social media, we can carry out various forms of exchange, collaboration and get acquainted with each other in the form of written, visual and audiovisual forms (Puntoadi, 2011: 11). One of the social media that is very popular and widely used today is Instagram

Instagram is an internet-based service as well as a social network for sharing stories via digital images (Sulianta, 2015: 119). With the rapid development of social media Instagram, now uploaded content is not just photos and captions that are uploaded to show the existence of an individual or a company. The content that is being uploaded a lot at this time, or which is also referred to as a trending phase, is creative content with a deeper meaning and is more focused and planned.

With the Instagram feature which provides the facility to upload not only a photo with writing but various other media such as videos, the content that can be uploaded becomes more diverse. Not to mention the Instagram insight feature that allows account owners to clearly see data regarding the engagement of uploaded content, content can be made more targeted, planned, and adjusted to the various goals of the account owner.

We can find various types of creative content while we are surfing the Instagram network. For example, @ xingfutang_indo nesia did many collaborations with celebrities and influencers to promote their products, as well as reposted many people's Instagram stories. This action was carried out in order to maintain good relations with the community. Not only promotion by means of collaboration, visual appearance and captions by@xingfutang_indonesia are packaged attractively so that potential consumers are curious and interested in trying products.

This creates a condition where using Instagram as a digital asset for companies as a medium that can reach its target market in a more focused manner and creates a two-way communication pattern that cannot be achieved if only using advertising media. In accordance with the background of the problem above, the author intends to further examine how the application of the copywriting element on the @ xingfutang_i ndo nesia Instagram account is able to create interest in the brand. Thus, the purpose of this study is to determine the application of the elements of headlines and 
slogans, taglines, and calls to action that create consumer interest in the brand.

The benefits of this research are expected to provide benefits, both academically and practically. In practical terms, it is hoped that this research can be a reference in the formation of a marketing communication strategy in communicating a brand by prioritizing copywriting that is in accordance with the target market and can be useful for @xingfutang_indonesia as the account owner to get more in-depth insights related to uploaded advertisements based on the results of analysis with strategies-research copywriting strategy.

\section{LITERATURE REVIEW}

\section{Primary Marketing Communication}

Communicatio $\mathrm{n}$ is an important thing in human life, including for business and corporate purposes. In a business or company, the communication that is carried out to run its business is marketing communicatio $n$ which is usually better known as integrated marketing communicatio $\mathrm{n}$ or integrated marketing communication Integrated marketing communication is the main key for a company in running its business. According to Shimp (2010: 7), integrated marketing communication is a critical aspect of the entire companys marketing mission and a major determinant of the success or failure of companies.

According to the American Association of Advertising Agencies (the "4As") stated in a book written by George E. Belch and Michael A. Belch (2009: 11) that the notion of integrated marketing communication is a marketing communication planning concept that realizes the added value of a comprehensive plan. which evaluates the strategic roles of the various communicatio $n$ disciplines for example, general communication direct response, sales promotion and public relations and combines these various disciplines to provide maximum clarity, consistency and impact of communication through comprehensive integration of disparate messages.

Integrated marketing communicatio $\mathrm{n}$ is the means by which companies attempt to inform persuade and remind consumers directly or indirectly about the products being sold. Marketing communication presents the "voice" of the company and its brand and is a means by which companies can communi cate and build relationships with consumers, and build brands in the minds of consumers by combining marketing communicatio $\mathrm{n}$ modes, namely advertising, persomal selling, sales promotion, direct marketing, publicity, and tools. - other communication tools.

\section{Integrated Marketing Communicat io n Strategy}

Integrated marketing communicatio $n$ consists of basic marketing tools to achieve the marketing communication objectives of a company. Elements of the marketing mix according to Belch \& Belch (2018: 16-27) consist of: (1) advertising, which is any for $\mathrm{m}$ of paid non-personal communicatio $n$ about an organization, product, service, or idea from a certain party, (2) direct marketing which involves a variety of activities, including database management, direct selling, remote marketing, and direct-response advertising by direct mail, online, and various broadcast and print media; (3) digital marketing, which is a new interactive media that allows users to carry out various activities such as receiving, changing and sharing information and images, making questions, answering questions, and even making online purchases; (4) sales promotion, namely marketing activities that provide extra value or incentives for salespeople, distributors or end 
consumers and can stimulate sales; (5) publicity and public relations to support integrated marketing communications of a company, (6) personal selling is a form of interpersonal communication in which the seller tries to help or persuade potential buyers to buy a product or service or act on something.

The marketing mix is usually carried out in tandem in order to achieve integrated marketing communications. With this marketing mix, companies can communi cate with their target market in one direction, such as advertising, to two directions with digital marketing. It is hoped that the development of a relationship with the target market will also embed a good brand image in the minds of the public.

\section{Internet Marketing}

The internet is a multi-aspect marketing communicatio $\mathrm{n}$ tool. In one aspect the internet is an advertising medium as ma ny marketers pay to place advertising banners promoting their products and services on the websites of other companies, organizations and publishers. Advertisers also pay for internet searchengines such as Google, Bing, and Yahoo! to place their ads in search results based on keywords (Belch \& Belch, 2014: 22). Paid search has become the most used form of internet advertising.

The internet can also be used as a marketing communication tool because it is a medium that can execute all elements of the marketing mix. Marketers use the internet to conduct direct marketing, persomal selling, and public relations activities more effectively and efficiently. The large number of advertisements and promotions that appear on the "third screen" has led to major developments in mobile marketing, namely promotional activities designed for cell phones, smartphones, tablets, and other tools including applications, messaging, commercial, and customer relationship manageme $\mathrm{nt}$.

The second stage of the internet revolution (often referred to as Web 2.0) where the focus is on collaboration and sharing among internet users. This has given rise to the development and growth of social media which refers online, meaning that communication and interaction between people is used to create, share and exchange content such as information, insights, perspective experiences, and the media itself. Social media has revolutionized how companies communicate, listen to and learn from their customers and has become a major marketing tool for most companies.

The interactive nature of the internet and social media is one of the main advantages of marketers. This capability allows marketers to gather valuable personal information from customers and prospects, as well as customize offers. Another advantage of the internet is that marketers can become closer to consumers and measure the effects of their advertisements. There are a number of measures that can be generated when consumers visit sites or spend time on social media, namely marketers can determine how consumers respond to their campaigns, how well marketers engage consumers, how big is the marketer's return on investment (Belch \& Belch, 2014: 23).

Social Media Marketing is a marketing technique that uses social media as a means of promoting a product or service. Social media marketing is more about the development and utilization of the social media area as a means or place to build target markets for online businesses. In the development of social media marketing, marketers must build a target market with intense

communication. 


\section{Social Media}

According to Nasrullah (2013: 43), social media is a media used to publish content such as profiles, activities or even user opinions as well as a medium that provides space for communication and interaction in social networks in cyberspace. In short, social media is a means of communication to many people in cyberspace that can be done anytime and anywhere.

Extraordinary marketing results can be generated through social media, people no longer watch television they watch more on or use their cellphones (Puntoadi, 2011: 19). Social media provides an opportunity to interact more closely with consumers, can be a medium for forming online communities. Social media can be part of an overall emarketing strategy combined with other social media. Social media provides opportunities to enter pre-existing communities and provides the opportunity to get feedback directly.

In the article entitled "User of the World, Unite! The Challenges and Opportunities of Social Media, "in Business Horizons magazine (2010: 69-68) accessed on 4 October 2019, Kaplan \& Haenlein made clarifications for the various types of social media that exist based on the characteristics of their users which basically can be divided into six type: (1) site collaborationproject; (2) blogs and microblogs; (3) content or content; (4) social networking sites; (5) virtual game world; (6) virtual social world.

\section{Instagram}

Instagram is a social media that connects users through photos. One of the interesting features of Instagram is that there is a photo boundary to a square shape, similar to the Kodak Instamatic, and polaroid images, which are very different from the current 16: 9 aspect ratio used by cellphone cameras
(Salbino, 2014: 47). Instagram's social media features are quite diverse, such as likes, shares, photo filters, Instagram stories, insights, even Instagram advertisements.

How many features and advantages of Instagram drive tremendous user growth, which ultimately makes Instagram the choice of various digital marketers to be used in digital marketing activities, especially as a medium for branding. Marketers have found Instagram very useful for sharing communication activities. For example, companies share news about an event, introduce new products, related activities to increase exposure (Belch \& Belch, 2014: 516).

\section{Copywriting}

Broadly speaking, advertising requires a persuasive message for marketing communications or public communicatio $n$ about a product (goods, services, or ideas). The definition of copywriting in "The ABC of Copywriting" according to Tom Albrighto $n$ (2013: 5), copywriting is the optimal use of language with the aim of promoting or persuading. According to Frank Jefkins in Agustrijanto (2006: 33) that copywriting is the art of writing the most persuasive and strong sales message, which is motivated by entrepreneurship through print media.

Creating a compelling advertising message requires creativity, especially in terms of copywriting. In the process of creating an advertisement, the compilation of a copywriting is very important, even absolute because in every line, no matter how many words it uses, the words will always be used to create magic in the product or service offered.

The writing must be able to attract attention (interest), desire (desire), trust (conviction), and action (action) as desired, otherwise the sales message or ad copy has 
failed. The main purpose of copywriting is shaping buying behavior. Copywriting is an advertising text material that has a significant share in the creation of advertising works, and is rich in sales messages. The composition of copywriting must actually be in line with and in accordance with the rules, orders, basic concepts, perceptions, principles and opinions of the audience. Ad placement must be communicated in such a way that the public can receive it well.

In concept, copywriting is made as attractive as possible to create audience curiosity about a product, then encourages the audience to know more about the product, and at its peak can continue to buy the product being offered. In his book "The ABC of Copywriting" Tom Albrighton says there are 6 important elements in building an attractive copy which includes:

(1) headlines and slogans, which are the most important parts of a copywriting uni $t$ to get the attention of the audience, adjust the emphasis of the content, determine the the me of the content, or provide emphasis information from the illustrations included; (2) structures; (3) company taglines to differentiate a brand from others, add character to the copy, or add value to benefits ; (4) metaphors and similes, differentiating one thing from another; (5) calls to action, which is a sentence or more that is inserted into a copy containing an invitation to do somethi ng concrete, such as buying, expressing interest, making a donation, and others in accordance with the purpose of making the copy, (6) case studies.

Making effective persuasive messages to attract consumers' attention requires an effective strategy in order to have the desired effect. An effective message strategy is a message in a campaign that must be able to convey promotional objectives. Moriarty (2009: 449) suggests 11 effective message strategies as follows: (1) message s that attract attention, using ideas that are compelling, curiosity, or visually dazzling; (2) messages that create interest, attract attention reflect the attractiveness of advertising, keep attention from distracting, reflect allure; (3) resonating messages, namely the emotional impact of creating a personal connection with the brand; (4) messages that create trust; (5) memorial messages; (6) emotionally touching messages; (7) messages that provide information; (8) messages that teach; (9) persuasive messages; (10) messages that create brand associations; (11) messages that trigger action

\section{Consume $r$ Characte ristics}

Consumers are the most strategic elements of a brand, because consumers are the source of their income. Therefore, knowledge of values, ways of thinking and consumer behavior is an important element for the realization of a good communicatio $n$ strategy (cognitive, affective, and behavioral factors).

Watono and Watono (2011: 104) say there are three aspects of consumer characteristics, namely Head, Heart, and Hand $(3 \mathrm{H})$. Head is a consumer characteristic that refers to consumer knowledge which cumulatively shapes consumer confidence in a brand. Heart is a consumer characteristic that refers to how consumers feel about the product / brand. Hand refers to consumer behavior in the form of the intention to do something about the product / brand.

Head, Heart, and Hand will shape consumer attitudes towards the product. The initial process (head) can be identified with consumer understanding and knowledge (brand awareness, brand association, brand image, brand identity, perceived quality, knowledge about product benefits and product value propositions, and communication messages that have been 
conveyed) which will build confidence. against a product. Furthermore, this belief will trigger consumer feelings (likes, loves, emotional relationships, satisfaction, loyalty, preferences, self-expression associated with brand identity, and motivation in choosing brands) which is called the heart process.

Consumers' feelings will eventually shape their behavior and intention to buy a product called the hand process. Consumer behavior includes consumer habits, product usage patterns, media consumption patterns, shopping behavior patterns, product information search patterns, and so on

\section{Creative Content}

According to the Big Indonesian Dictionary (KBBI), the word "creative" has the meaning of being creative or creative, while the word "content" itself according to KBBI means information available in media or electronic products. From the meaning of KBBI itself, it can be interpreted that creative content is information available in media or electronic products that are creative in nature. According to Mike Villiers, as a senior lecturer at Birmingham City University and an expert on Brand Strategy and Creative Content, in an article uploaded by Marissa Selanon on her personal blog https://marisaselanon.wordpress.com/2013/0 7/16/ creative-content-the-core-of-digital marketing/(accessed December 20, 2019), creative content is defined as a story, film or promotional video. Something that was created for promotional purposes in a creative way.

\section{Online Engagement}

Online engagement can be defined as a psychological condition of social media users categorized by interactivity, co-creative user experience with an account owner. To operate online engagement on Instagr am, likes, post shares, profile visits, impressions, and comments are tools used to represent online engagement. A post with lots of likes can indicate that a piece of content is said to be interesting, increase the likelihood that someone will also like it, and lead to the spread of information about a brand to potential customers.

On the other hand, a large number of comments on a post represents a level of success or impact because comments make users take the time to share their opinions. Likes and comments have been widely used as a measure of the impact of a publication Online engagement is important because the more online engagement one achieves, the more likely it is that a brand will be better known. In addition, online engagement is also important because it can show good relations with consumers and have an impact on consumer loyalty.

\section{RESEARCH METHODS}

This research uses a qualitative approach Qualitative research is concerned with developing explanations for social phenomena (Hancock, Ockleford, \& Kate Windridge, 2009: 7). In qualitative research, data collection is not guided by theory, but is guided by facts found during research in the field.

This study uses a descriptive method in which the author only describes the events. Descriptive research describes systematically a situation, problem, phemomeno $n$ service or program or provides information about the living conditions of a community or describes an attitude towards a problem

Based on the description above, the authors in this study explain in depth about the application of the copywriting element in advertisements on Instagr am @xingfutang_i ndo nesia. The discussion is in 
the form of a copywriting element uploaded by @xingfutang_i ndonesia on Instagram

The data collection technique used is the documentation of a collection of content in which there are elements of copywriting from Instagram @xingfutang_i ndo nesia and in-depth interviews with copywriters and content creators@xingfutang_indo nesia who play a role in creating related content on Instagram The documentation data is a supporter that can help the author in researching the copywriting elements of content on social media Instagr am @xingfutang_indo nesia

\section{RESULTS AND DISCUSSION}

Creative content uploads on the @xingfutang_i ndo nesia Instagram account were made in an effort to attract the attention of the target market which is one of the marketing activities of @xingfutang_i ndo nesia as a businessman as well as a marketer. In every creative content creation, @xingfutang_indo nesia as a content creator uses techniques in the preparation of each content as a basic foundation for delivering the content to a broad target market so that creative content can have an impact on the target market of @ xingfutang_i ndo nesia itself.

In this study, the author implements the elements of copywriting according to Tom Albrighton in his book "The ABC of Copywriting" into creative content uploaded on the@xingfutang_indo nesia Instagram account. The elements that will be discussed by the researcher include headlines and slogans, company taglines, and calls to action contained in the creative content of Instagr am @xingfutang_indo nesia.

\section{Headline and Slogans}

According to Tom Albrighton (2013: 33 ), headlines will tell the whole content of the content. In other situations, headlines can be supported by additional text. The use of a headline is to get the attention of the target market, set the emphasis of the content, set the theme of the content, or provide emphasi s information from the illustrations included. Based on the expert opinion described above, the writer wants to try to match the facts obtained, namely the data that the researchers obtained from Instagram @ xingfutang_i ndo nesia.

In creative content uploaded by @ xingfutang_indo nesia on December 27, 2019, @xingfutang_i ndo nesia applied the headlins element in the form of a statement which was included in the thumbnail section of the upload. The headline is in the form of the words "Soft Opening".

Informants also stated that the placement of headlines in content is one of the important things to attract the attention of the target market. The creative content creation technique applied by the informants is to create content followed by the use of headlines on the first photo from a series of multiple posts uploaded. From these findings, creative content does not only contain plain visuals without writing, but when it comes to lifting content that talks about informatio n, headline elements must also be applied to clarify the information to be conveyed through the creative content uploaded.

In the creative content uploaded by @ xingfuta ng_i ndonesia on January 8, 2020, researchers also found the application of the headline element in the @xingfutang_i ndonesia upload. The headline element contained in this upload is in the for $m$ of a statement explaining the contents of the uploaded creative content, where in the upload@xingfutang_i ndonesia raises the content of the new branch opening. The 
words on the headlines are "Grand Opening". As said by Tom Albrighton, the headline element must be a clear statement about the visual or illustration that is displayed with it, the application of the headline from the creative content fulfills its function.

Informants also said that the application of headlines to creative content uploaded by @xingfutang_indo nesia aims to provide information to the target market about the content. The use of headlines aims to make it easier for the target market to find information on the creative content uploaded via thumbnails on the @xingfutang_i ndo nesia Instagram account. Likewise with the slogans element applied by @xingfutang_indonesia in every creative content. Both uploads have a slogan contained in the caption in the form of "\#happinessis here".

The author opened an Instagr am account @xingfutang_indo nesia on January 10, 2020 and found that the two posts previously discussed received a significant number of likes and comments. On the first upload, there were 1,622 likes and 98 comments. On the second upload, there were 1,189 likes and 60 comments. This indicates that the creative content uploaded by @xingfutang_i ndonesia can be said to be interesting so that it is liked by many people and is successful by getting a large number of comments.

From these findings, it was found that creative content uploaded by @ xingfutang_i ndo nesia with headlines could shape consumer attitudes towards products based on Head, Heart, and Hand according to Watono and Watomo (2011: 105). Creative content@xingfutang_i ndonesia is able to provide understanding and knowledge to consumers who influence their cognitive process, mamely the head which is then followed by feelings of the brand / product such as attraction related to the affective factor, mamely heart. Behaviorally, the target market can be said to have reached the hand process with media consumption patterns, namely by providing comments in uploading creative content @xingfutang_indo nesia.

In the headline and slogans element, it was found that @xingfutang_indonesia used these elements in creative content uploaded on the@xingfutang_indo nesia Instagram account where headlines and slogans were arranged attractively to attract the attention of the target market to be interested in the creative content.

\section{Company Tagline}

According to Tom Albrighton (2013: 43) a copy can use a tagline to distinguish a brand from another, add character to the copy, or add value to benefits. In implementing this element,@xingfutang_indonesia also includes the tagline that has been created into every uploaded creative content. However, the application of this element is not included in the thumbnail or caption, but is in the @xingfutang_i ndo nesia logo itself. The author found the application of the company taglines element in the creative content inserted in the logo section in all uploads of creative content @xingfutang_indo mesia, namely "Taiwan No.1".

In applying the company tagline element, the author finds that this element has been applied consistently in every upload of creative content @xingfutang_i ndo mesia in the form of a logo. The informant also confirmed this with the company tagline which is usually placed together with logos such as Disney's company tagline, namely "The Happiest Place On Earth".

The author found that every @ xingfutang_i ndo nesia upload from November 16, 2019 to January 15, 2020, with the application of the company tagline in the logo, got high engagement, both in terms of 
likes and comments. Based on Head, Heart, and Hand according to Watono and Wato no (2011: 105), it can be concluded that @xingfutang_indonesia is able to create cognitive and affective linkages, even behavior.

In its application on Instagram social media, @xingfutang_indo nesia found that the use of a company tagline in a logo is one of the things that is commonly used and one of the most effective ways to convey a company tagline. I also found the application of this company tagline element from the creative content uploaded by @xingfutang_i ndo nes i a itself where the logo in each upload was carried out consistently and had the same content.

\section{Call to Action}

According to Tom Albrighton (2013: 54 ), a call to action is a sentence or more that is inserted into a copy which contains an invitation to take real action such as buying, expressing interest, making domations, and others in accordance with the purpose of making the copy. The author also found that creative content on the @xingfutang_indo nesia Instagram account did not escape using these elements.

In every upload of creative content @xingfutang_indo nesia in the period 16 November 2019 to 15 January 2020, researchers can find the application of calls to action in almost every upload of creative content @xingfutang_i ndo nesia. The author found that the application of call to action in social media, especially Instagram, is to provoke interaction from the audience in the form of engagement such as giving likes, giving comments, sharing content through the target audience's personal accounts, and watching Instagram TV.

In uploading creative content on January 7, 2020, @xingfutang_i ndo nesia invites its audience to call to action elements to buy their products and get angpao from @ xingfutang_i ndo nesia. Regarding the application of the call-to-action elements found by the author, the informant also said that in a creative content, there must be a purpose that the creative content creator wants to convey.

The informant also stated that the call to action element that is included in creative content can make the audience more interested in taking concrete actions on the creative content uploaded, in this case including interactions in the form of likes, comments, and shares. The author also found another form of application of call to action in creative content @xingfutang_i ndo mesia in the form of an invitation to share Christmas greetings with one of the properties of @ xingfutang_i ndo nesia on the audience's Instagram story. Researchers found this application in the creative content uploaded on December 23, 2019.

The two uploads of @ xingfutang_i ndo nesia received positive responses from the audience which can be seen from the number of likes and comments. Uploads on January 7, 2020 received 5,789 likes and 83 comments. Uploaded on December 23, 2019 received 3,159 likes and 40 comments.

If you look at the number of likes and comments listed and based on the concept of Head, Heart, and Hand according to Wato no and Watono (2011: 105), it can be said that @xingfutang_i ndo nesia succeeded in building audience knowledge about the brand, sparking audience interest in creative content represented by numbers likes, and the intention of the media consumption pattern in the form of giving comments.

In the calls to action element, it is found that@xingfutang_indo nesia has implemented this element in its creative content. From the results of the analysis 
obtained by the author, the call to action element contained in the creative content @ xingfutang_indonesia is an invitation sentence to do something or creates an interest and in this case, it is found that the similarities of what has been done by @xingfutang_i ndo nesia itself which always includes invitation elements in its creative content. The use of this element in the creative content of @xingfutang_i ndo mesia is applied by including the call to action in the caption colum in each upload.

\section{CONCLUSIONS AND SUGGESTIONS}

Creative content is one of the company's tools to promote its products. Creative content does not escape the visual and copywriting elements in it. The application of the copywriting element is one of the important things in creating creative content to help get high online engagement. Therefore, the application of the copywriting element is something that must receive special attention in order to achieve this goal.

The application of headlines and slogans elements to creative content uploaded by @xingfutang_indo nesia in the time span starting from November 16, 2019 to Januar y 15, 2020, has been applied to the uploaded creative content. Headlines and slogans are used to make it easier for the audience from @xingfutang_i ndonesia itself to find out information from creative content uploaded either via thumbnails or captions on the @xingfutang_i ndonesia Instagram account. Headlines and slogans are also packaged in an attractive manner to attract the audience's interest to access the creative content. Headlines in the form of statements on thumbnails in feeds and slogans in the for $m$ of hashtags in captions are made with the aim of making it easier to search for content on the
@ xingfutang_i ndo nesia Instagram feed as well as attracting audience interest.

The application of the company tagline element to the creative content @ xingfutang_i ndo nesia starting from November 16, 2019 to January 15, 2020, has been applied to creative content that is inserted in the form of a logo. Placement of the company tagline on the logo is one way to keep the target market in mind.

The call to action element in the creative content@xingfutang_indonesia uploaded from November 16, 2019 to Januar y 15, 2020 has been applied to the uploaded creative content. The application of call to action elements in uploaded creative content in the form of invitation sentences in the caption colum of a post. The invitation can be in the form of an invitation to buy a product, visit a store, interact with the target audience, watch Instagram TV, and upload an Instagram story by placing the label @ xingfutang_i ndo nesia.

These three elements are also able to create engagement between the target market and @xingfutang_i ndonesia. In other words, copywriting from @xingfutang_i ndo nesia is proven to be able to influence the target market both cognitive, affective, and behavior, which can be seen from the number of likes and comments on each existing upload.

Copywriting on social media is one of the important factors that cannot be separated from the shifting of content that occurs in social media today, where content has turned into creative content to attract more audiences, so it is hoped that this research can be used as evaluation material related to the application of copywriting elements on social media and @xingfutang_i ndo nesia can develop copywriting techniques that are used to develop creative content that is made better in the future. 


\section{REFERENCES}

Agustrijanto (2006), Copywriting Seni Mengasah Kreatifitas dan Memahami Bahasa Iklan, Bandung: PT Remaja Rosdakarya.

Albrighton, Tom (2013), The ABC of Copywriting, Norwich: ABC Business Communicatio ns Ltd.

Belch George E. dan Michael A. Belch (2009), Advertising and Promotion: An Integrated Marketing Communication Perspective, Edisi 8, New York: McGraw-Hill.

(2014), Advertising and

Promotion: An Integrated Marketing Communication Perspective, Edisi 10, Vancouver: Langara College. (2018), Advertising and Promotion: An Integrated Marketing Communication Perspective, Edisi 11, International Edition, New York: McGraw-Hill Education

Moriarty, Sandra, et al (2009), Advertising, Edisi 8, Jakarta: Kencana

Morissan (2010), Periklanan Komunikasi Pemasaran Terpadu, Jakarta: Kencana Prenada Media Grup.

Nasrullah, Rulli. (2013), Cyber Media, Yogyakarta: IDEA Press.

Puntoadi, Danis. (2011), Menciptakan Penjualan Melalui Sosial Media, Jakarta: PT Elex Media Komputindo.

Salbino, Sherief. (2014), Buku Pintar Gadget Android Untuk Pemula, Jakarta: Kunc i Komunikasi.

Shimp, Terence. A. (2010), Integrated Marketing Communication in Advertising and Promotion, Edisi 8, South-Western Cengage Learning. Sulianta, Feri. (2015), Keajaiban Sosial Media, Jakarta: Elex Media Komputindo. Watono, A. Adji dan Maya C. Watono (2011), IMC: Integrated Marketing
Communication that Sells, Jakarta: PT Gramedia.

Hancock, B., et al 2010, An Introduction to Qualitative Research, https://www.rdsyh.nihr.ac.uk/wp-

content/uploads/2013/05/5 Introductio n-to-qualitative-research-2009.pdf, diakses 1 November 2019.

Kamus Besar Bahasa Indonesia. (2019), Kamus Besar Bahasa Indonesia, Badan Pengembanga n Bahasa dan Perbukua n \& Kementerian Pendidikan dan Kebudayaan Republik Indonesia, https://kbbi.kemdikbud. go.id/entri/kont en, diakses 20 Desember 2019.

Kamus Besar Bahasa Indonesia. (2019), Kamus Besar Bahasa Indonesia, Badan Pengembanga $\mathrm{n}$ Bahasa dan Perbukua $\mathrm{n}$ \& Kementerian Pendidikan dan Kebudayaan Republik Indonesia, https://kbbi.kemdikbud. go.id/entri/krea tif, diakses 20 Desember 2019.

Kaplan, Andreas M. \& Haenlein, Michael 2010, 'User of the World, Unite! The Challenges and Opportunities of Social Media',

https://www.slideshare.net/Twittercrisi s/kaplan-and-haenlein-2010-socialmedia., diakses 4 Oktober 2019.

Selanon, Marisa 2013, 'Creative Content: The Core Digital of Marketing', https $/ /$ marisaselan on.wordpress.com/2013 /07/16/creative-content-the-core-of digital-mar ket ing/, diakses 20 Desember 2019.

VIVA 2018. Blued, Aplikasi Pecinta Sesama Jenis dengan 27 Juta Pengguna, (Online), (https://www.viva.co.id/arsip/996784 -blued-aplikasi-pecinta-sesama-jenisdengan-27-juta-pengguna. Diakses 9 November 2019).

Woodward, Kathryn (ed.). 2002. Identity and Difference. London: SAGE Publications. 
Yulius, Hendri. 2019. C*BUL: Perbincanga n

Serius tentang Seksualitas

Kontemporer. Tangerang Selatan: Marjin Kiri. 